\title{
Emissary Foramens of the Human Skull: Anatomical Characteristics and its Relations with Clinical Neurosurgery
}

\author{
Forámenes Emisarios del Cráneo Humano: Características Anatómicas \\ y sus Relaciones con la Neurocirugía Clínica
}

\begin{abstract}
Alexandre Rodrigues Freire*; Ana Cláudia Rossi"; Viviane Cristina Souza de Oliveira**; Felippe Bevilacqua Prado*; Paulo Henrique Ferreira Caria* \& Paulo Roberto Botacin***
\end{abstract}

FREIRE, A. R.; ROSSI, A. C.; DE OLIVEIRA, V. C. S.; PRADO, F. B.; CARIA, P. H. F. \& BOTACIN, P. R. Emissary foramens of the human skull: Anatomical characteristics and its relations with clinical neurosurgery. Int. J. Morphol., 31(1):287-292, 2013.

SUMMARY: The recognition of emissary foramens is important not only for understanding the regional neurovascular anatomy, but also to distinguish normal from potentially abnormal structures. Thus, the aim of this study was to review the literature on anatomical and clinical aspects of the mastoid, parietal and sphenoid emissary foramens. It was found that the emissary foramen presents importance in clinical practice because it acts as a route of spread of extracranial infection to the intracranial structures and also possible complications in neurosurgery, due to its influence in the performance of techniques such as radiofrequency rhizotomy for treatment of trigeminal neuralgia. The anatomical knowledge of the emissary foramens is important due to variability in their incidence in the human skull and its relation to the dura mater sinuses.

KEYWORDS: Emissary foramens; Veins; Neurosurgery; Dura mater.

\section{INTRODUCTION}

Anatomical variations of foramens of the skull have been of interest for neuroanatomists due to clinical consequences that these structures can cause, especially in the areas as neurosurgery and dentistry. These anatomical variations tend to be neglected by clinicians and most are mentioned or described as "rare" or "occasional" in human anatomy books. However, the knowledge of three-dimensional topographic anatomy of skull structures and their morphometric values is necessary but not sufficient for performing of a safe treatment, thus it is suggested that detailed knowledge of anatomical variations is essential for students in health areas who on work the head and neck (Keskil et al., 2003).

Along the skull, there are numerous foramens through which course vital neural and vascular structures. Recognition of these foramens is important not only for understanding the regional neurovascular anatomy, but also to distinguish normal from potentially abnormal structures. The poor interpretation of such variations occasionally creates complications during clinical interventions.
Therefore, some procedure failures can occur around the foramen during instrumentation near those areas causing trauma to vascular and neural structures (Gözil et al., 1995).

Anatomical studies have focused on the various foramens of the human skull including emissary foramens. The emissary foramens allow the passage of emissary veins that connect the intracranial venous sinuses with extracranial veins of the scalp (Standring, 2005).

Emissary veins act as output veins of the neurocranium and drainage of venous blood from cephalic structures. Although these veins are valved, they allow the blood flow in both directions. Under normal circumstances, blood flow through these veins is slow. However, in cases of increased intracranial pressure, the emissary veins become an important source of drainage of blood (Reis et al., 2007).

Emissary foramens, as the parietal and mastoid (the most known), are noted with greater frequency in the human skull, while the sphenoid emissary foramen, because it is

* Department of Morphology, Anatomy Area, State University of Campinas - UNICAMP, Piracicaba, São Paulo, Brazil.

** Camilo Castelo Branco University, Fernandópolis, SP, Brazil.

**** Department of Basic Sciences, Anatomy Area, Paulista State University - UNESP, Araçatuba, São Paulo, Brazil. 
less studied by clinical, needs a through approach to avoid interpretation errors during procedures in neurosurgery and clinical dentistry (Sicher \& DuBrul, 1977; Gupta et al., 2005; Louis Jr. et al., 2009; Rossi et al., 2010).

Considering the importance of knowing the implications of the anatomical variations of the human skull can generate during clinical procedures, the aim of this study was to review the literature on anatomical and clinical aspects of the mastoid, parietal and sphenoid emissary foramens.

\section{Literature Review}

Mastoid Foramen. The emissary mastoid foramen is located at the mastoid portion of the temporal bone, near to occipitomastoid suture (Fig. 1). This foramen can also appear on the occipitomastoid suture and, if present, transmits an emissary vein to sigmoid sinus. It can occur in single or multiple (Sicher \& DuBrul).

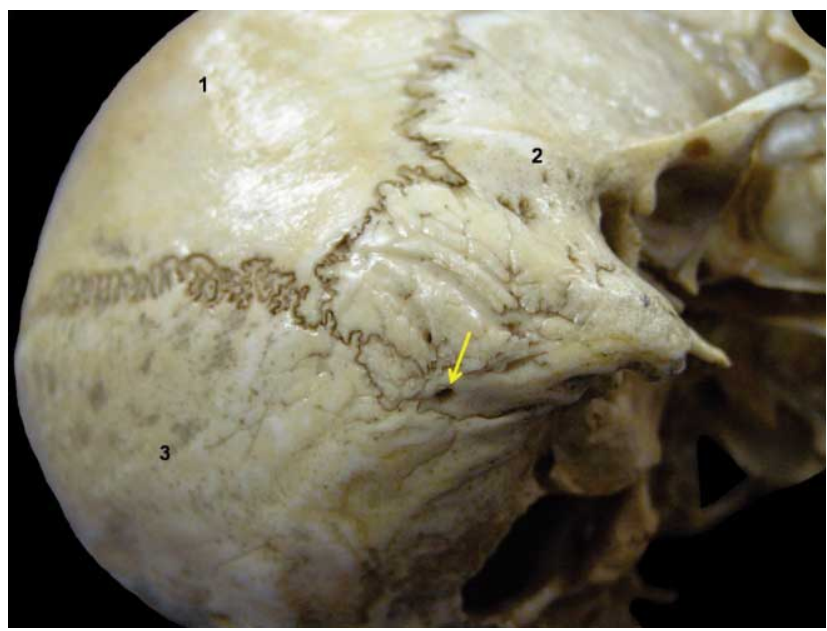

Fig. 1. Latero-posterior view of an adult skull. The arrow indicates the presence of the mastoid foramen. 1. Mastoid part of temporal bone; 2. Parietal bone; 3. Occipital bone.

The knowledge of anatomy of the posterior neck region and its anatomical variations such as the existence of the foramen mastoid and its emissary vein is important to understand the clinical presentation and treatment of complications such asbleeding during neurosurgical access and in cases of venous thromboembolism (El Kettani et al., 2002).

It was verified that the mastoid emissary vein courses through mastoid foramen,connecting the sigmoid sinus to posterior auricular and occipital veins (El Kettani et al). Under normal circumstances, the blood that runs through this vein is slow. However, in cases of intracranial venous hypertension, the mastoid emissary vein can become a resource for blood drainage (Reis et al.).
The mastoid emissary vein may act as another route of spread of infection or tumors originated in the face and infratemporal fossa (Sicher \& DuBrul).

In addition, the mastoid foramen is considered an anatomical landmark that helps in the differentiation of species and, thus, was verified their importance in forensic anthropology (Reis et al.). It is believed that the adaptation of a bipedal hominid position was associated with anatomical and physiological changes in the venous system of the skull base to adapt to the concomitant changes in intracranial venous blood flow. The pattern of venous drainage of the Australopithecus was based on the occipital vein. In homo sapiens, the volume of this drainage was reduced occurring, thus, the development of new veins. Among these new veins, the emissary mastoid vein led to the emergence of the mastoid foramen in the modern human skull (Falk, 1986).

These evolutionary changes have shown that the sigmoid sinus drains into the vertebral venous plexus when is in the upright position and drains into the internal jugular vein when is in the supine position (Goucha et al., 2002).

Boyd (1930) found an incidence of $68 \%$ of the mastoid foramen in a sample of 1478 skulls of modern human, while Falk obtained a 90\% incidence in a sample of 51 skulls of early human. Reis et al., found an incidence of $89 \%$ of the mastoid foramen in a sample of 40 cadaveric modern human. Moreover, the mastoid foramen is less frequent in the skulls of non-human primates such as chimpanzees and gorillas. During hominid evolution, the diameter of the mastoid emissary vein and the namesake foramen, probably, increased (Falk).

Goucha et al., suggested that the remodeling and thinning of the mastoid process along the hominid evolution has been postulated to correlate with the development of the emissary mastoid vein and its namesake foramen.

Parietal Foramen. The parietal foramen (Fig. 2) is located laterally to the sagittal suture, at the boundary between the posterior third and middle third of this suture. This foramen usually occurs bilaterally, however, may appear unilaterally or to be absent (Sicher \& DuBrul, 1977).

The different occurrences of the parietal foramen (absent, unilateral, bilateral, single at the middle position) are present due to differences in ossification process of the anterior fonticulus. In some cases, a small transverse parietal suture is found in one or both sides at this region (Yoshioka et al., 2006). 


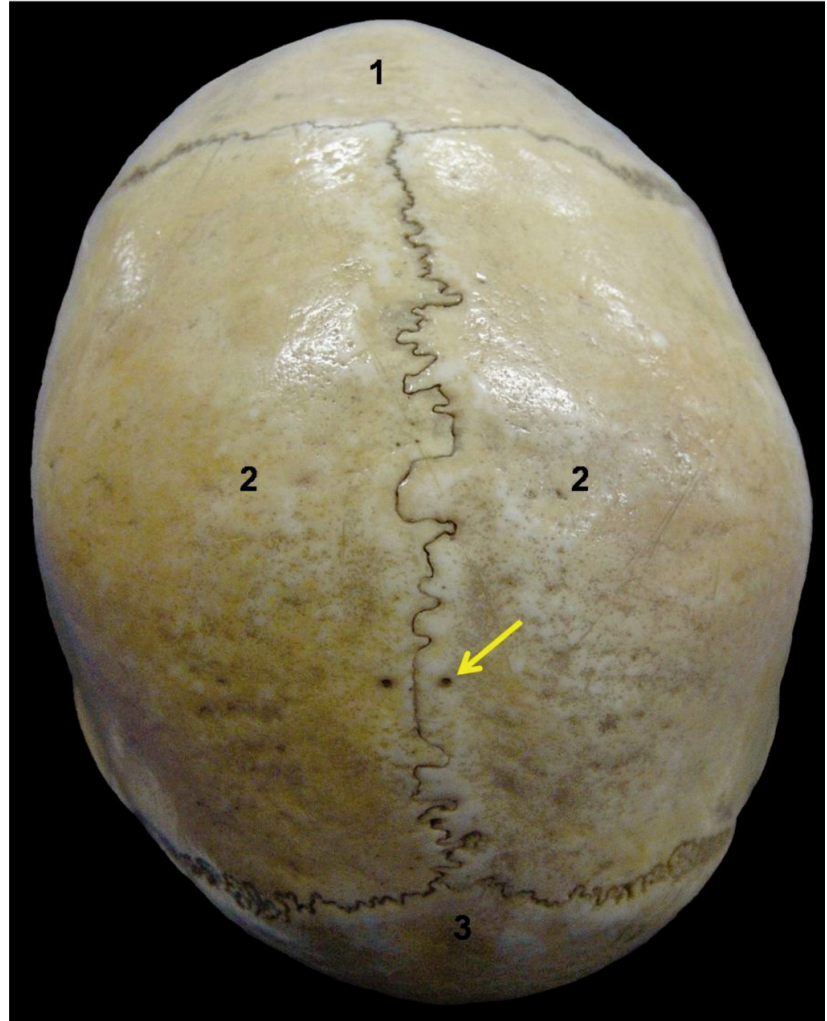

Fig. 2. Superior view of an adult skull. The arrow indicates the presence of bilateral parietal foramen. 1. Frontal bone; 2. Parietal bone; 3 Occipital bone.

The presence of parietal foramen can be considered normal, but when it is found with an excessive opening can be defined as the occurrence of a disorder in the formation and growth of the bone tissue (Wysocki et al., 2006).

It was found in the literature that the parietal foramen incidence ranges from 50 to $80 \%$ in different population groups and, moreover, has been reported small variations in number, location, size and shape (Yoshioka et al.; Wysocki et al.).

According to the position it was found that the parietal foramen in newborns is located $2 \mathrm{~cm}$ anterior to the craniometric point lambda. While in adults, this foramen is located 2-5 cm anterior to the external occipital protuberance (Wysocki et al.).

Wysocki et al., found an average size twice major in female skulls than in males $(3 \mathrm{~mm}$ in females and to $1.5 \mathrm{~mm}$ in males), ranging from 0.38 to $16.8 \mathrm{~mm}$ in Polish female population, thus suggesting a sexual dimorphism in the parietal ossification. Boyd have reported that the average size of this foramen is less than $0.5 \mathrm{~mm}$ and a size larger than $1.5 \mathrm{~mm}$ is rare.
Moreover, it was reported that the parietal foramen may occur in the following forms: circular, oval or fissure aspect (O`Rahilly \& Twohig, 1952; Mann, 1990; Keats, 1992).

Few studies reported the localization, incidence and variations of the parietal foramen, and even less about the possible relationship between the parietal foramen and complexity of the sagittal suture in humans (Topinard, 1878; Currarino, 1976). However, it was found that this foramen presents clinical significance because it allows the passage of an emissary vein connecting the veins of the scalp veins with the superior sagittal sinus, with regard not only to the drainage of the scalp, but also with the spread infection to the sinuses of the dura mater (Sicher \& DuBrul, 1977).

Sphenoidal emissary foramen . At the base of the skull, there is an emissary foramen situated in the sphenoid bone called the sphenoidal emissary foramen (Sicher \& DuBrul; Ramalho et al.), or foramen of Vesalius (Shapiro \& Robinson, 1967; Sicher \& DuBrul; Gupta et al.; Rossi et al.; Wysocki et al.; Shinohara et al., 2010), considered uncommon in several studies (Shapiro \& Robinson; Gupta et al.; Rossi et al.; Wysocki et al.; Shinohara et al.).

The sphenoidal emissary foramen is located at anterior and medial in relation to the foramen ovale, which can be seen in internal view of the skull (Fig. 3) and the inferior view (Fig. 4). This foramen allows the passage of an emissary vein, which communicates the structures of the face, through pterigoid plexus, with the cavernous sinus (Gray et al., 1995; Kocaogullar et al., 2003; Reymond et al., 2005).

Studies have reported the incidence of the sphenoidal emissary foramen and described that it is very variable. Rossi et al., showed that from the analysis of 80 skulls, the overall



Fig. 3. Internal view of an adult skull. FV. Sphenoidal emissary foramen (Foramen venosum/Foramen of Vesalius; FO. Foramen ovale. 


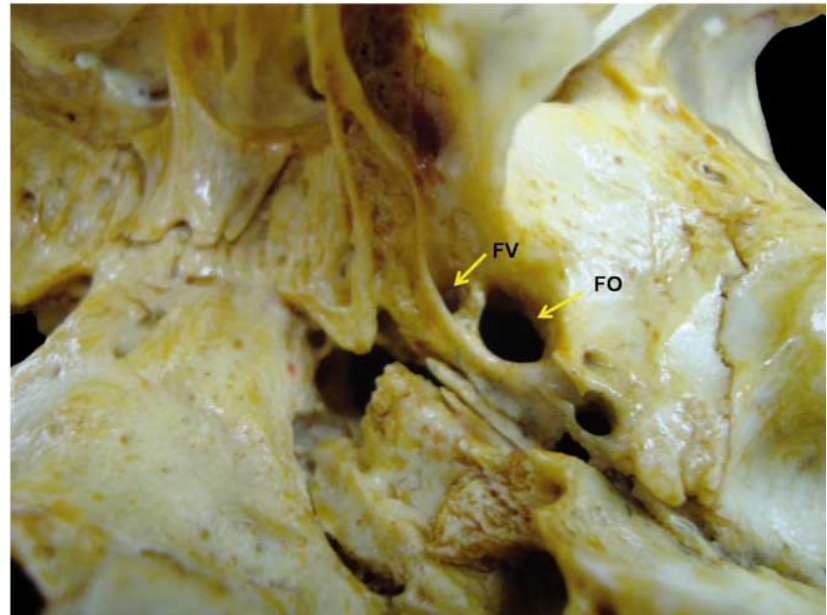

Fig. 4. Inferior view (skull base) of an adult skull. FV. Sphenoidal emissary foramen (Foramen venosum/ Foramen of Vesalius); FO. Foramen ovale.

incidence was 40\%. Lang et al., and Bergman et al. (1995), found a similar incidence of $40 \%$. Table I shows the overall incidences of the sphenoidal emissary foramen and incidences according to the side found in the studies reviewed.

Regarding the diameter, Rossi et al., found an average of $1.45 \pm 1.043 \mathrm{~mm}$ on the right side and $1.59 \pm 0.938 \mathrm{~mm}$ on the left. Shinohara et al., found an average diameter of $0.69 \mathrm{~mm}$ and $0.72 \mathrm{~mm}$ on the right and left side, respectively. According to Boyd (1930), in 65\% of cases, the sphenoidal emissary foramen may appear with diameter of $0.5 \mathrm{~mm}$. On the other hand, the mean diameter found by Kaplan et al. (2007), was $1 \mathrm{~mm}$.

The distance from the sphenoidal emissary foramen in relation to the foramen ovale also has been measured. Rossi et al., measured an average distance of $1.853 \pm 0.303 \mathrm{~mm}$ on the right side and $2.464 \pm 0.311 \mathrm{~mm}$ on the left from 80 skulls. Were also reported this distance by Shinohara et al., and these authors measured $2.55 \mathrm{~mm}$ on the right side and $2.59 \mathrm{~mm}$ on the left from 400 skulls. In the study by Rossi et al., found a remarkable partial fusion between the sphenoidal emissary foramen and the foramen ovale. Shinohara et al., also reported the presence of duplicated foramen.

The sphenoidal emissary foramen allows the passage of an emissary vein that connects the pterygoid venous plexus to the cavernous sinus. The cavernous sinus is a dependency of dura mater at the base of the skull (Kaalin \& Robinson, 1984).

Thus, septic thrombus from extra-cranial source can reach the cavernous sinus generating a thrombophlebitis
(Sicher \& DuBrul). Thrombophlebitis or septic thrombosis may occur through dissemination by contiguity through periphlebitis at sinus drainage to the cavernous sinus or by septic embolism. The pair sinuses (lateral, cavernous, petrosal) are the most commonly affected (Simon, 1996).

The septic thrombosis is caused by suppurative processes at the orbit, paranasal sinuses or the upper half of face level, such as boils, sinusitis or otitis (Casella et al., 1998). Although is rare, can have correlation with dental infection (Kaalin \& Robinson). Among the various symptoms that can occur due to the involvement of cranial nerves, when the mandibular nerve is compromised, the trismus is present. Exceptionally, the region of the maxillary nerve is also affected. Moreover, it is common to the spread of infection to the contralateral cavernous sinus through the circular sinus (Casella et al.).

Trigeminal neuralgia is characterized by paroxysms of shock pain, which presents short duration and is recurrent, in the somatosensory distribution of one or more branches of the trigeminal nerve. The cause of trigeminal neuralgia is still under discussion, but the compression of the trigeminal nerve by a vascular loop is the most frequent finding during exploration of cerebellar-pontine angle. The pain is usually relieved after microvascular decompression (Gusmão et al., 2003). For treatment of trigeminal neuralgia is used the trans-ovale approach by rhizotomy associated to fluoroscopy to guide a needle puncture to the trigeminal impression (Gusmão et al.).

One important aspect of this treatment is the foramen ovale penetration (Tator \& Rowed, 1976). When reaching the foramen ovale, the needle is placed at the third branch of the trigeminal nerve (Gusmão et al.). The needle may erroneously penetrate the sphenoidal emissary foramen, with the consequent puncture of the cavernous sinus. Gusmão et al., stated that the failures of this technique range 0.5 to $4 \%$ with an average of $2.7 \%$. Sweet (1968) reported the needle penetration at the sphenoidal emissary foramen in 09 cases, being 08 there were no adverse consequences, but in 1 case there was a temporal lobe hemorrhage. Sindou et al. (1987), reported error of needle puncture to the trigeminal impression in 10 cases of 200: 2 at the carotid canal, 1 at the jugular foramen and 7 at the sphenoidal emissary foramen.

Studies by Sindou et al., and Sweet demonstrated that the proximity to the sphenoidal emissary foramen to foramen ovale increases the likelihood of errors in some techniques to treat of trigeminal neuralgia. In fact, studies by Rossi et al., and Shinohara et al., demonstrated that the average distance between these two foramens is short. 
FREIRE, A. R.; ROSSI, A. C.; DE OLIVEIRA, V. C. S.; PRADO, F. B.; CARIA, P. H. F. \& BOTACIN, P. R. Emissary foramens of the human skull: Anatomical characteristics and its relations with clinical neurosurgery. Int. J. Morphol., 31(1):287-292, 2013.

Table I. Overall incidences of the emissary sphenoid foramen and incidences according to the side found in the studies reviewed.

\begin{tabular}{|c|c|c|c|c|c|c|}
\hline \multirow[t]{3}{*}{ Authors } & \multirow[t]{3}{*}{$\mathbf{N}$} & \multicolumn{5}{|c|}{ Incidence } \\
\hline & & \multirow[t]{2}{*}{ Overall (\%) } & \multicolumn{2}{|c|}{ Side $(\%)$} & \multicolumn{2}{|c|}{ Side (\%) } \\
\hline & & & Right & Left & Unilateral & Bilateral \\
\hline Boyd & - & 36,5 & 10,6 & 11,2 & - & 12,5 \\
\hline Lang et al. & - & 40 & 49 & 36 & - & - \\
\hline Bergman et al & - & 40 & - & - & 13 & - \\
\hline Gupta et al & - & 32,85 & 20 & 12,85 & 20 & 22 \\
\hline Reymond et al & - & 22 & - & - & - & - \\
\hline Ramalho et al & 64 & 71,87 & - & - & - & - \\
\hline Kaplan et al & 10 & 100 & - & - & - & - \\
\hline Rossi et al & 80 & 40 & 15,62 & 11,25 & 6,25 & 13,75 \\
\hline Shinohara et al & 400 & 33,75 & 7,75 & 10,5 & 18,25 & 15,5 \\
\hline
\end{tabular}

In the technique of the rhizotomy by radiofrequency, the needle associated to a specialized electrode is placed at ganglion of the trigeminal nerve, and its correct position generates a mild electrical stimulation that produces tingling sensations in the face. The electrode is then heated to produce a thermal nerve injury, while the patient is under heavy sedation. This form of percutaneous rhizotomy has the best pain control in the long time, about three quarters of patients pain-free after five years (Gusmão et al., 2003).

In conclusion, the anatomical knowledge of the emissary foramens and their clinical implications are important in clinical practice, mainly due to variability in their incidence in the human skull and its relation to the sinuses of the dura mater.

FREIRE, A. R.; ROSSI, A. C.; DE OLIVEIRA, V. C. S.; PRADO, F. B.; CARIA, P. H. F. \& BOTACIN, P. R. Forámenes emisarios del cráneo humano: Características anatómicas y sus relaciones con la neurocirugía clínica. Int. J. Morphol., 31(1):287-292, 2013.

RESUMEN: El reconocimiento de forámenes emisarios es importante no sólo para la comprensión de la anatomía neurovascular regional, sino también para distinguir lo normal a partir de estructuras potencialmente anormales. El objetivo de este estudio fue revisar la literatura sobre los aspectos anatómicos y clínicos del proceso mastoide, huesos parietal y esfenoides y forámenes emisarios. El foramen emisario adquiere importancia en la práctica clínica debido a que actúa como una vía de propagación de la infección extracraneal a las estructuras intracraneales, y también con las posibles complicaciones en neurocirugía, debido a su influencia en el desarrollo de técnicas como rizotomía por radiofrecuencia en el tratamiento de neuralgia del trigémino. El conocimiento anatómico de los forámenes emisarios es importante debido a la variabilidad en su incidencia en el cráneo humano y su relación con los senos de la duramadre.

PALABRAS CLAVE: Foramen; Venas emisarias; Neurocirugía; Duramadre.

\section{REFERENCES}

Bergman, R. A.; Afifi, A. K. \& Miyauchi, R. Illustrated Encyclopedia of Human Anatomic Variation: opus V: skeletal systems: cranium, 1995.

Boyd, G.I. Emissary foramina of cranium in man and the anthropoids. J. Anat., 65:108-21, 1930.

Casella, A .M. B.; Monteiro, M. L. R.; Rgensteiner, D. B. W. \& Caldeira, J. B. F. Regeneração aberrante do nervo do oculomotor após tromboflebite do seio cavernoso. Arq. Bras. Oftalmol., 51:135-7, 1998.

Currarino, G. Normal variants and congenital anomalies in the region of the obelion. Am. J. Roentgenol., 127(3): 487-94, 1976.

El Kettani, C.; Badaoui, R.; Fikri, M.; Jeanjean, P.; Montpellier, D.; Tchaoussov, J. Pulmonary edema after venous air embolism during craniotomy. Eur. J. Anaesthesiol., 19:846-8, 2002. 
Falk, D. Evolution of cranial blood drainage in hominids: enlarged occipital/marginal sinuses and emissary foramina. Am. J. Phys. Anthropol., 70:311-24, 1986.

Goucha, S.; Mnif, M.; Bouhala, T.; Tenzakhti, F.; El Andaloussi, H.; Fazaa, B.; Hamza, R. \& Kamoun, M. R. Value of imaging in GAPO syndrome. J. Radiol., 83: 153-156, 2002.

Gözil, R.; Kadioglu, D. \& Calguner, E. Occipital emissary foramen in skulls from Central Anatolia. Act. Anat., 153: 325-6, 1995.

Gray, H.; Bannister, L. H.; Berry, M. \& William, PL. Osteology. In. Gray, H.; Bannister, L.H.; Berry, M. \& William, P.L. Gray's Anatomy. 38th ed. London: Churchill Livingstone, 1995.

Gupta, N.; Ray, B. \& Ghosh, S. Anatomic characteristics of foramen Vesalius. Kath. Univ. Med. J., 3(2):155-8, 2005.

Gusmão, S.; Magaldi, M. \& Arantes, A. Rizotomia trigeminal por radiofrequência para tratamento da neuralgia do trigêmio. Arq. Neuropsiq., 61(2):434-40, 2003.

Kaalin, R. J. \& Robinson, W. A. Septic cavernous sinus thrombosis. Ann. Emerg. Med., 13:449-55, 1984.

Kaplan, M.; Erol, F. S.; Ozveren, M. F.; Topsakal, C.; Sam, B. \& Tekdemir, I. Review of complications due to foramen ovale puncture. J. Clin. Neurosci., 14(6):563-8, 2007.

Keats, T. E. Atlas of normal roentgen variants that may simulate disease. $5^{\text {th }}$ edition. St. Louis, Mosby Year Book, 1992.

Keskil, S.; Gözil, R. \& Calgüner, E. Common surgical pitfalls in the skull. Surg. Neurol., 59(3): 228-31, 2003.

Kocaogullar, Y.; Avci, E.; Fossett, D. \& Caputy, A. The extradural subtemporal keyhole approach to the sphenocavernous region: anatomic considerations. Minim. Invas. Neurosurg., 46(2):100-5, 2003.

Lang, J. Clinical anatomy of the head, neurocranium, orbit and craniocervical region. Springer, Berlin, 1983.

Louis Jr, R. G.; Loukas, M.; Wartmann, C.T.; Tubbs, R.S.; Apaydin, N.; Gupta, A. A.; Spentzouris, G.; Ysique, J. R. Clinical anatomy of the mastoid and occipital emissary veins in a large series. Surg. Radiol. Anat., 31139-144, 2009.

Mann, R.W. Enlarged parietal foramina and craniosynostosis in an American Indian child. Am. J. Roentgenol., 154(3):658, 1990.

O'Rahilly, R. \& Twohig, M.J. Foramina parietalia permagna. Am. J. Roentgenol., 67(4):551-61, 1952.

Ramalho, J. C.; Sousa-Rodrigues, C. F.; Rodas, P. M. M.; Lins, C. J. P.; Lima, R. L.; Neto, E. T. D. L.; Neto, J. A. B. S. A incidência e as relações morfométricas do forame emissário do esfenóide em crânios humanos. Int. J. Morphol. (abstract)., 25(1):145, 2007.

Reis, C.; Deshmukh, V.; Zabramski, J. M.; Crusius, M.; Desmuskh, P.; Spetzler, R. E. \& Preul, M.C. Anatomy of the mastoid emissary vein and venous system of the posterior neck region: neurosurgical implications. Neurosurg., 61:ONS193-ONS201, 2007.
Reymond, J.; Charuta, A. \& Wysocki, J. The morphology and morphometry of the foramina of the greater wing of the human sphenoid bone. Folia Morphol., 64(3): 188-193, 2005.

Rossi, A. C.; Freire, A. R.; Prado, F. B.; Caria, P. H. F.; Botacin, P.R. Morphological characteristics of foramen of Vesalius and its relationship with clinical implications. J. Morphol. Sci., 27(1): 26-9, 2010.

Shapiro, R.; Robinson, F. The foramina of the middle fossa: a phylogenetic, anatomic and pathologic study. Am. J.Roentgenol., 101:779-94, 1967.

Shinohara, A. L.; Melo, C. G. S.; Silveira, E. M. V.; Lauris, J. R.P.; Andreo, J. C. \& Rodrigues, A. C. Incidence, morphology and morphometry of the foramen of Vesalius: complementary study for a safer planning and execution of the trigeminal rhizotomy technique. Surg. Radiol. Anat., 32:159-64, 2010.

Sicher, H. \& DuBrul, E.L. Oral Anatomy. $6^{\text {th }}$ ed. Rio de Janeiro: Guanabara Koogan, 1977.

Simon, R. P. Parameningeal infections. In: Bennett, J.C. \& Plum, F. Cecil textbook of medicine. $20^{\text {th }}$. Philadelphia: Saunders, 1996.

Sindou, M.; Keravel, Y.; Abdennebi, B.; Szapiro, J. Traitement neurochirurgical de la névralgie trigéminale: abord direct ou métode percutané? Neurochirur, 33:89-111, 1987.

Standring, S. Gray's anatomy. $3^{\text {th }}$ edition. Elsevier Churchill Livingstone, Edinburgh, 2005.

Sweet, W. H. Trigeminal neuralgias. In: Alling, C.C. Facial pain. Philadelphia: Lea \& Febiger, 1968.

Tator, C. H. \& Rowed, D.W. Fluoroscopy of foramen ovale as an aid to thermocoagulation of the gasserian ganglion. J. Neurosurg., 44:2547, 1976.

Topinard, P. Anthropology. London, Chapman and Hall, 1878.

Wysocki, J.; Reymond, J.; Skarz ynski, H. \& Wróbel, B. The size of selected human skull foramina in relation to skull capacity. Folia Morphol., 66(4): 301-08, 2006.

Yoshioka, N.; Rhoton, A. L. \& Abe, H. Scalp to meningeal arterial anastomosis in the parietal foramen. Neurosurg., 58(1):123-6, 2006.

Correspondence

Alexandre Rodrigues Freire

PhD Student

Av. Limeira, 901 P.O. Box: 52

Department of Morphology

State University of Campinas

UNICAMP, 13414-903

Piracicaba, SP,

BRAZIL

E-mail: alefreire@fop.unicamp.br

Received: 01-05-2012

Accepted: 27-12-2012 